\title{
Technology and Learning by Factory Workers: The Stretch-Out at Lowell, 1842
}

\author{
By James Bessen*
}

$7 / 02$

\begin{abstract}
In 1842, Lowell textile firms increased weaving productivity by assigning three looms per worker instead of two. This marked a turning point. Before, weavers at Lowell were temporary and mostly literate Yankee farm girls; afterwards, firms increasingly hired local residents, including illiterate and Irish workers. An important factor was on-the-job learning. Literate workers learned new technology faster, but local workers stayed longer. Human capital calculations show these changes were unprofitable before 1842 and that the advantages of literacy declined over time. Firm policy and social institutions slowly changed to permit deeper human capital investment and more productive implementation of technology.
\end{abstract}

Keywords: Industrial Revolution, technological change, learning-by-doing, human capital

JEL codes: O30, N61, J24

James Bessen

Research on Innovation and Visiting Scholar, MIT Sloan School of Management

jbessen@ researchoninnovation.org

\footnotetext{
* Thanks to Bob Hunt, David Landes, Tim Leunig, John Lyons, Bob Margo, David Mitch, John Murray, Gavin Wright, anonymous referees and participants at the Economic History Association and seminars at the Federal Reserve Bank of Philadelphia and University of Maryland, Baltimore County. Many thanks also to Tom Brush, Margaretha Hendrickx and William Lazonick for their patient assistance in providing data. This research was supported by Research on Innovation.
} 
This paper revisits the interaction of technological and social change in antebellum Lowell Massachusetts. Specifically, it looks at changes that took place around one pivotal event, the "stretch-out of 1842."

In April of 1842, Mill No. 2 of the Lawrence Company switched permanently from two looms per worker to three looms per worker (four looms after 1851). Prior to then, each worker tended two looms except during occasional periods when waterpower was rationed or when labor supply was insufficient. Beginning in early 1842, the mills in Lowell began experimenting with different numbers of looms per worker and different loom speeds [Dublin, 1993, p. 109]. In April 1842, all weavers in the Upper Weave Room of Mill No. 2 appear to have been assigned three looms and other Lowell mills made the switch at about the same time. ${ }^{1}$

The initial impetus for this transition appears to have been depressed demand, not technological change. James Montgomery was in Lowell at the time he was revising Cotton Manufacture. A thorough observer of all things technical, he attributed the change to poor demand, not to anything technical [1840, p. 132]. He opined that the mills would revert to two looms per worker once business revived, but this did not happen.

This change, in fact, marked an important turning point. The greater capital intensity substantially increased labor productivity. Also, it signified the beginning of the end of the "Waltham system" of labor supply. Through 1842 the weavers were predominately literate Yankee farm girls who lived mainly in boardinghouses during their relatively short stays in Lowell. After 1842, the mills gradually began hiring more illiterate workers and Irish immigrants for weaving jobs, including many who were local permanent residents.

These changes pose a problem. If three looms per worker were more productive, why, then, had the textile firms used only two looms for the previous two decades? And what, if anything, did this change in production have to do with the change in labor supply, especially since the labor change occurred well after the production change? This paper argues that a critical factor in these changes was the human capital of individual weavers.

The next section presents a brief overview of the argument. I hold that traditional explanations of the change in labor supply do not adequately account for the details of this change and that worker experience may be an important consideration. In the second section, I present evidence of the importance of worker human capital for textile technologies and, using micro-data, I estimate sizeable human capital investments arising from on-the-job learning among the weavers in Mill No. 2.

\footnotetext{
${ }^{1}$ Judging from changes in capital productivity, the speed of the looms was reduced and gradually restored to its original level over the next two years. Montgomery states that speeds were reduced by about 15\% [1840, p. 132 (notes added later)].
} 
In the third section, I combine these estimates with data on worker turnover to show that the Lawrence Company could not have profitably assigned three looms per worker much earlier. I extend these calculations in the fourth section to show that the profit advantage of literate workers declined gradually over time.

I conclude that this evidence highlights the importance of worker skills learned on the job for the implementation of the power loom. The efficient adoption of this technology had to wait for a more stable workforce and the growth of a pool of experienced workers available for rehire. This, in turn, depended on the slow development of social institutions and firm policy. The adoption of this new technology was a broad social process dependent on more than just a few inventors and entrepreneurs.

This paper differs from much of the previous research on antebellum Lowell in its use of micro-data. Davis and Stettler [1966], McGouldrick [1968], Williamson [1972], Zevin [1975], David [1975], and Nickless [1979] study productivity growth at the firm or industry level. David, in particular, identifies the importance of learning-by-doing at an aggregate level. The analysis here measures learning by individual workers and specifically links this to technical and social changes.

Boot [1995] obtains estimates of the human capital investments made by male workers in the Lancashire cotton industry. I find somewhat smaller investments made by female weavers. However, in addition, I find a much larger investment made by employers in the human capital of the weavers.

Lazonick and Brush [1985] also use micro-data to investigate changes in work intensity in Lowell (data they graciously shared with me). The analysis here focuses on the behavior of employers, complementing their research.

\section{An Overview of the Argument}

The changes in labor supply in the Upper Weaving Room of Lawrence Co. Mill No.2 are illustrated in Figure 1. This graph displays annual characteristics of new hires including literacy (determined by signature on the payroll register), non-Irish ethnicity (determined by surname) and previous experience (a description of the data is provided in the Appendix). Since inexperienced workers were usually paid on a day rate for several weeks before receiving piece rate wages, I assume that new hires who began on piece rate had previous experience. ${ }^{2}$ The figure also displays previously experienced hires who were either illiterate or Irish.

\footnotetext{
2 As a check, the productivity level of such workers was close to the productivity of workers who acquired substantial experience after beginning on day rate.
} 
This figure poses a problem for traditional historical accounts. Ware [1931] and Josephson [1949] long ago recognized these changes in literacy and ethnicity and linked them to the greater intensification of work. In their view, the employers acted initially on philanthropic motives [Ware, 1931, p. 64]. Here the historians have followed the early hagiography of Francis Cabot Lowell who, after visiting Lancashire, established the Waltham system of manufactures to avoid the "corrupting and debasing influences which have almost universally marked manufacturing cities abroad" [Miles, 1846, p. 215, see also Appleton, 1858].

But according to this view, by the 1840s, more intense competition drove manufacturers to reduce wages, speed up (run the machinery faster) and stretch out (more machines per worker) [Ware, 1931, p. 113, 230, Josephson, 1949]. Manufacturers could get away with this greater "exploitation" because the mills began hiring Irish and "low class" New Englanders who were more submissive.

More recent scholarship by Lazonick and Brush [1985] provides evidence that work did intensify during the 1840s and that changes in the labor supply supported this intensification. But Lazonick and Brush do not attempt to develop a complete picture of employers' motivation for these changes and, in particular, of the timing of these changes.

Indeed, explanations dependent on early employer paternalism have several problems. The Lowell employers did lower piece rates during the early decades, e.g., a large reduction in 1834. Moreover, employers could have hired allegedly docile Irish and "low class" girls during the early decades, but did not. ${ }^{3}$ It is hard to see why philanthropists would have spurned these needier classes, especially when they might have improved profits.

More significantly, Figure 1 shows that the timing of this story is off. The stretch-out to three looms per worker occurred in 1842 before many immigrant or illiterate workers were hired and while the workforce was still supposedly more resistant. Lawrence Co. only gradually began hiring more illiterate and Irish workers after 1842 and the majority of new hires were non-Irish until 1854 and literate until 1855. Something other than employers' philanthropic instincts was driving these changes.

A clue to an alternative explanation is found in Figure 1. By 1842, the fraction of new hires with previous experience had risen substantially. The workers at Lowell had high turnover, sometimes $10-15 \%$ per month, and many worked intermittently. The rising fraction of experienced hires suggests that a pool of such workers available for rehire developed over time. If worker

\footnotetext{
3 Of about 600 adult Irish in Lowell in 1835, only 50 were employed as factory workers; most Irish women went into domestic service, instead [Ware, 1931, p. 229]. Also, when Irish did enter the factories, they were assigned to low-paying departments [Dublin, 1993, p. 148], not weaving.
} 
experience mattered for productivity and if capital deepening raised the premium on this experience, then the development of this pool may have shifted employers' calculations of the optimal number of looms per worker. If, after accounting for turnover and replacement, employers could maintain a more experienced workforce in 1842, they may have found three looms per worker more profitable then, but not earlier.

Figure 2 illustrates the changing importance of individual worker experience. This figure displays the mean yards of cloth per hour produced by new loom tenders according to their months on the job- "learning curves."4 Means for two balanced panels of workers are displayed, one from 1833-36, when each worker tended two looms, and one from 1842-55, when workers tended three or four looms. During their first months on the job, inexperienced new hires were far less productive than comparable experienced workers were. Moreover, the relative disadvantage of inexperienced workers was much larger when workers tended three or four looms. After 1842, the learning periods were longer-nearly a year, compared to about six months during the earlier period-and the relative productivity differences were greater.

Thus the retention of experienced workers and the pool of experienced replacements may have been critical to the profitable implementation of three looms per worker. Below, I calculate human capital investments for workers and the firm and show that, in fact, changes in turnover and the labor pool made the switch profitable in 1842, but not in 1834 .

Moreover, the characteristics of the labor supply affected the growth of the pool of experienced labor. Figure 1 shows that most of the increase in the hiring of experienced workers after 1845 consisted of illiterate and/or Irish workers. The shift in the labor supply thus appears to enhance the growth of the labor pool.

I argue that the increasing importance of the pool meant a declining advantage associated with literacy. Below I present evidence that literate workers had an important productivity advantage over illiterate workers during the early years. Literate workers were apparently better at acquiring the detail skills that were learned through experience. This advantage was important for the productivity of the initial power loom installations. Francis Cabot Lowell's first successful mill using power looms hired a select group of literate Yankee farm girls who resided temporarily in boardinghouses. This type of labor supply was different from that used in earlier textile mills and it was also used at the mills in Lowell through the 1820s and 1830s. I show that in 1834 literacy was still necessary for profitable operation at the Lawrence Company.

\footnotetext{
4 This figure excludes workers who spent no time on day rate-these were presumed to have previous experience-and those workers who spent more than 72 days on day rate. The latter consisted primarily of "permanent" dayhands who taught new workers and served as utility workers.
} 
However, other evidence below shows that this labor supply had two limitations affecting the experience level of the workforce. First, literate workers were more likely to leave the mill once they became proficient; they had higher turnover. Second, once they left the mill, they were also more likely to leave the town. Yet experienced local workers were more available to re-enter the workforce. The local workforce tended to include many more illiterate and Irish workers, so the increased importance of the pool of experienced workers implied greater participation by illiterate and Irish workers. Calculations below show that the strong advantage of literate workers in the 1830s gradually disappears and reverses by the mid-1850s. As more illiterate and Irish workers entered the workforce, their presence in the pool of local labor also grew, reinforcing the trend. The greater importance of on-the-job learning after 1842 and again with four looms per worker in the 1850s meant a gradual shift to a local workforce. These shifts in hiring policy undermined the social institutions of the Waltham system and introduced what became the standard American separation between work and residence.

Note that these long-term changes occurred over several decades even though individual learning was a short-term phenomenon. That is, individual workers took only a year or less to acquire the skills needed for top performance. Nevertheless, the development of the labor market institutions and firm policies needed to acquire and maintain an experienced workforce took decades.

\section{Human Capital of Power Loom Tenders}

\section{Individual Learning Curves and the Technology of the Industrial Revolution}

Since I attribute an important role to learning on-the-job, it is helpful to begin with a careful look at the importance of experience for factory jobs.

Indeed, it is not obvious why experience on-the-job should be important for tending automated machinery. As Landes [1969] describes it, the technologies of the Industrial Revolution worked on a principle of replacing some skilled manual operations with power-assisted machinery. The workers at Lowell tended several looms (eventually twenty or thirty looms) driven by waterpower, replacing skilled weavers. The mule spinner, who spun cotton on a thousand spindles assisted by steam power, replaced the cottage spinster who spun on a single manually powered spindle. Yet although multiplying the number of machines per worker increased throughput, it also increased defects, often by a more than proportional factor. ${ }^{5}$ Defects idled the expensive

\footnotetext{
5 In extreme cases, for instance, all the threads on a spinning mule could break at once, causing a "sawney" and a substantial loss in productivity [Catling, 1970].
} 
machinery, lowering the utilization rate. This, in turn, put a premium on worker's precision and reliability. Workers who allowed fewer defects and who fixed them faster would realize a higher utilization rate and higher productivity.

There is evidence that nineteenth century firms were quite concerned with issues of utilization and defects. Mule spinners were assisted by "piecers" to fix breaks ("piecing" together broken ends of yarn). In Stanway's survey of 151 Lancashire cotton mills in 1833, piecers comprised 59\% of the labor force in mule spinning and much of the spinners' labor was occupied with piecing as well [Parliamentary Papers, 1834, XIX, D.1, p. 125]. The piecers' wages figured prominently in contemporary evaluations of various spinning technologies, including mule carriages with a greater number of spindles [Parliamentary Papers, 1834, XIX, D.1, p. 119] and the "self-acting" (automatic) mules [Montgomery, 1840]. Indeed, von Tunzelman calculates that additional piecing costs made the self-acting mule uneconomical for fine yarns in 1835 [1978].

Similarly, estimates of idle time and effective throughput are found in calculations for power looms [Montgomery, 1840, p. 142, Ure, 1836, Vol. 2, p. 312]. Power loom tenders fixed yarn breaks, filled empty shuttles, and corrected various machine errors such as "smashes," when the shuttle stopped in the weft, but the loom kept on running. Lyons [1987] cites data that welloperated power looms of the 1830's achieved utilization rates (actual production rate divided by machine rate) from $75 \%$ to $80 \%$.

But it was also known that new hires would achieve a much lower rate of utilization and hence their production was far less. In 1859 the managing agent of a Chicopee mill wrote that it was desirable "to induce [new hires] to remain more than one year which is all that our contract requires of them. They will be worth more to us the last six months than they are the first twelve [Shlakman, 1935, p. 147].” That is, productivity and utilization doubled after a year. In other words, workers climbed individual learning curves.

The learning curves in Figure 2 can be attributed almost entirely to changes in utilization as new workers acquired greater skill. ${ }^{6}$ All the looms in the Upper Weave Room were typically run at a fixed rate and departures from the maximum rate of output can be attributed to idle time. Assuming that fully trained workers operated at $80 \%$ utilization, then, during the first month on the job, the utilization rate was only about $21 \%$ for workers in 1833-36 tending two looms, and was about $17 \%$ for workers in $1842-55$ tending three or four looms.

\footnotetext{
${ }^{6}$ It is possible that the increases in productivity might arise from exogenous technical change or plant-level learning effects. This is, however, unlikely for two reasons. First, these charts display averages for different cohorts; any general productivity improvements that occur between cohorts would be averaged out (this is not the case with Figure 1, however). Second, the charts plateau rather rapidly, showing no significant productivity gain after the initial learning period. This visual observation is supported by a regression analysis below.
} 
Skill was clearly important in achieving reasonable utilization of this relatively expensive equipment. This kind of learning process has been described as a process of trial-and-error search [Jovanovic and Nyarko, 1995, Muth, 1986, Auerswald et al, 2000]. In these models, productivity follows a "learning curve"-over time, through experience under different conditions and with repeated trials, a worker's productivity increases as knowledge of efficient techniques is acquired. After a certain level of productivity is reached, the worker stops searching and uses the best technique found. ${ }^{7}$ The loom tenders conducted this search for technique in noisy surroundings, working persistently for long hours, so they simultaneously learned to cope with these new conditions.

\section{A Model of Utilization and Learning}

This general description of individual learning curves can be formalized in a simple model of an individual production function. Let $y$ be the output per worker-hour, let $n$ be the number of machines per worker (spindles or looms), let $q$ be the maximum output rate per machine, and let $u$ be the utilization rate. Generally then

$$
y=n \cdot q \cdot u \text {. }
$$

Now $u$ will be a function of both $n$ and of the worker's skill; specifically, $u$ will decrease with $n$ and will increase with skill. The discussion of Figure 2 above reveals further points about skill: (1) Skill increases with work experience, $x$; (2) But only up to a point, that is, only in the domain $x \leq \bar{x}$, and (3) The effective training period also varies (increases) with $n$, that is, $\bar{x}=\bar{x}(n)$. Using these insights, I define "effective experience" as

$$
z(x, n) \equiv \min (x, \bar{x}(n)) .
$$

Then the individual production function can be written

$$
y(z, n)=n \cdot q \cdot u(z, n) .
$$

Below I estimate individual production functions of this form.

Now low initial productivity for a new employee implies a learning cost. A standard measure of human capital investment is discounted foregone output [Becker, 1993, pp. 30-33]. This can be seen in a simple model in discrete time, $t=0,1, \ldots$, where all learning occurs during the first period, and employees never terminate employment (see Figure 3). Suppose that an employee at the firm earns $w_{0}$ during the training period and $w_{T}$ thereafter. In alternative

7 This property of "optimal stopping" is a general feature of search models where there is an opportunity cost or direct cost of 
employment this employee could earn $w$. This employee faces an opportunity cost (that is, a human capital investment) of $I_{w} \equiv w-w_{0}$ that earns a return of $w_{T}-w$ in each subsequent period. Now in a competitive labor market, the employee will be indifferent between working at the firm and taking alternative employment, that is, the present values of both income streams will be equal. When this is true, the return on investment, $w_{T}-w$, will equal $r \cdot I_{w}$, where $r$ is the discount rate. Then it is easy to show (see Figure 3) that the worker's investment is

$$
I_{w} \equiv w-w_{0}=\frac{w_{T}-w_{0}}{1+r}
$$

the discounted quantity of "foregone" wages.

Similarly, given product price $p$ and capital rental (per machine), $c$, the firm will earn profits per worker of $\pi_{0}=p \cdot y(0, n)-w_{0}-n \cdot c$ during the first period and $\pi_{T}=p \cdot y(\bar{x}, n)-w_{T}-n \cdot c$ thereafter. If the firm can achieve profits of $\pi$ in other activities, and if capital markets are in equilibrium, then the firm's human capital investment is

$$
I_{f} \equiv \pi-\pi_{0}=\frac{\pi_{T}-\pi_{0}}{1+r}
$$

and total human capital investment is

$$
I \equiv I_{w}+I_{f}=p \cdot C, \quad C \equiv \frac{y(\bar{x}, n)-y(0, n)}{1+r}
$$

where $C$ is the discounted quantity of foregone output.

In the Appendix, I extend this analysis to multiple periods so that (4) and (6) become

$$
I_{w}=\sum_{x=0}^{\bar{x}} \frac{w(\bar{x})-w(x)}{(1+r)^{x+1}} \text { and } \quad C=\sum_{x=0}^{\bar{x}} \frac{y(\bar{x}, n)-y(x, n)}{(1+r)^{x+1}} .
$$

These equations hold also when employee separations are allowed after the training period. Wages and labor productivity can be observed for each period and for the plateau level. Thus the total human capital investment and also the worker's share can be calculated without explicitly assuming a value for the alternative wage (but assuming $r$ ). Below I check this calculation with one using an alternative wage. Also, these measures ignore separations occurring during the training period. In the Appendix, I also describe a procedure for calculating human capital investment allowing for separations during training. Both sets of measures are estimated below.

Note that the total human capital investment depends on the individual production function, (3), and thus on the firm's choice of machines per worker, $n$. That is, the firm jointly chooses the capital intensity and the level of human capital investment. This differs from other treatments where human capital is considered exogenous to the firm. Much of the analysis below 
concerns how firms make this decision to maximize profits. In the Appendix, I derive an expression for the steady state profits of the firm, assuming that the firm replaces workers who quit or are fired:

$$
\bar{\pi}=p \cdot y(\bar{x}, n)-w-n \cdot c-(d+r) \cdot I(n)
$$

where $d$ is the permanent employee separation rate. ${ }^{8}$ This equation has a simple interpretation. The last term represents the rent on human capital. The separation rate acts like "depreciation" of human capital: as workers leave and are replaced, the last term represents the cost of training replacement workers plus the return on investment.

This equation provides a useful framework for analyzing aspects of firm behavior below. Note that the separation rates are not entirely exogenous. For instance, firm hiring practices could influence the rate of separations. Thus the choice of capital intensity also involved consideration of different labor policies.

\section{Measuring human capital of unskilled loom tenders}

Using these definitions, I measure the human capital investment made in the Lawrence Company power loom weavers. I perform these calculations based on the mean labor productivity and mean wages by month of experience for balanced panels of workers using both estimation methods.

These estimates are shown in Table 1. During the 1830's loom tenders required an investment of $\$ 33$ by the first measure and $\$ 47$ by the second measure. By the 1840 's this investment increased to $\$ 95$ by the first measure and $\$ 162$ by the second.

The workers' share of this human capital investment was much smaller. Loom tenders invested only $\$ 6.42$ during the first period and \$23.31 during the second (using the second method, $\$ 9.03$ and $\$ 32.39$ respectively).

The methods used to calculate these investments do not explicitly assume a value for the alternative wage. To check these calculations, I compared the calculation for loom tenders during the 1830s (ignoring separations) to calculations made using two different alternative wages: the wages of Massachusetts female school teachers (\$11.28/month) and of New England females in cotton manufacturing from Goldin and Sokoloff's [1984] regression analysis for 1832 (\$11.98/month). These calculations generated estimates of $\$ 3.87$ and $\$ 5.04$, respectively. These figures are somewhat lower than my estimate of $\$ 6.42$, but the "true" alternative wage must take

\footnotetext{
8 As noted in the Appendix, in a model where the human capital investment is shared between workers and firms and where workers can leave one employer and use their skills at another, $d$ is the rate of permanent separations from the industry.
} 
10 - Technology and Learning by Factory Workers - July, 2002

account of compensating differentials (for factory hours and discipline) and selectivity (loom tenders were among the higher "quality" cotton workers).

These human capital investments can be compared with estimates of the training costs of apprentices. Apprentices' human capital investments can be estimated several different ways. Using British data from 1906, Elbaum [1989] makes a "generous estimate" that annual training costs were about 30 to 40 percent of the apprentice wage. He estimates that apprentices in 1906 earned about 3s less per week than youths in other employment. More [1980] reports somewhat smaller differentials. Assuming a six year apprenticeship and a 5\% discount rate, Elbaum's generous figures imply that the present value of training costs was no more than $£ 40$ or about $\$ 190$ in 1906. This suggests that training costs in the 1840's were significantly less than $\$ 190$-real training costs were unlikely to be greater in an age of simpler technology and nominal wages were about 50\% higher in 1906 than in the 1840's in Britain. Moreover, American skilled craftsmen earned roughly the same pay as their British counterparts in the early nineteenth century [Brito and Williamson, 1973, Rosenberg, 1967].

Internal rates of return provide another way to estimate the training costs of apprentices. Elbaum and Singh [1995] also estimate the internal rate of return on apprentice training in Britain in 1906. Using a skill premium of just under $40 \%$ (relative to semi-skilled occupations), they find an internal rate of return of 24\%. In the antebellum United States, Margo finds skill premia of 32\% for carpenters and $43 \%$ for masons relative to teamsters, a semi-skilled occupation [Margo, 2000]. Using an internal rate of return of $24 \%$ and wages of $\$ 1.25$ for carpenters and $\$ 1.50$ for masons, training costs were, respectively, $\$ 165$ and $\$ 253 .{ }^{9}$

Taking both of these estimates into account, male craftsmen in the 1840s probably required an investment of from $\$ 150$ to $\$ 250$, not much higher than the estimated $\$ 162$ invested in power loom tenders after 1842. Moreover, this latter investment was made in workers who had rather brief careers in the mills. Among weavers, turnover was very high, many workers did not complete even these brief training periods, and those who did only worked for several years in the mills [Dublin, 1979].

And contemporaries were aware of the significance of this investment:

"Operatives entering the mill at once receive pay. In other arts they are obliged to go through some expensive process of learning. The young woman from the country, employed at first as a spare hand, and a pupil to the business, receives fifty-five cents per week (sic) besides her board. Thus the companies educate nearly all their hands, and as

\footnotetext{
${ }^{9}$ This calculation assumes that the apprentice earned a constant differential less than alternative employment for six years, the same for one year, and then earned a premium for 30 years. The discount rate was 5\%. A lower premium or higher internal rates of return reduce estimated investment. I also assume year-round work which may mean that investments are overstated for masons.
} 
these hands are entirely changed every few years, they have at all times thousands in their pay as mere learners." [Miles, 1846, p. 112]

For the firms, these investments were not particularly large compared to the investment in physical capital per worker (see Table 1). But for the workers, these investments were quite substantial, especially given the uncertainty of the job match. Thomas Dublin estimates the property assets of the fathers of the Yankee mill girls as \$338 in 1830 and $\$ 960$ in 1850 [p. 35]. The human capital investments thus represented a significant portion of family wealth, especially for an uncertain and short-term investment. And after 1845 many of the weavers were Irish immigrants who had no such wealth. As shown in Table 1, the investments were also large relative to a trained worker's annual pay. It is not surprising then, that in contrast to apprenticeshipwhere workers effectively bore the full cost of human capital investment [Elbaum and Singh, 1995] — factory workers contributed only a fraction of the total investment as seen in Table 1.

These calculations imply that the mills paid workers less than their marginal product - the mills earned rents that permitted an adequate return on their human capital investment. ${ }^{10}$ In classic human capital theory, this occurs when the human capital is firm-specific [Becker 1993, Hashimoto, 1981]. Although loom tenders had skills that were industry-specific, by 1855 over $70 \%$ of the new hires at Lawrence Mill No. 2 had previous experience. Many must have gained this experience at other firms, so the skills could not have been very firm-specific.

Recent theoretical and empirical work finds other instances where firms earn rents and pay for general training. ${ }^{11}$ Following the analysis of Acemoglu and Pischke [1999], if the mills could earn rents (for any reason), then, given piece rate wages, they would have had an incentive to pay for general skills - more productive workers were more profitable. At Lowell, the mills had a degree of monopsony power. The mills, in fact, set wages jointly and in numerous instances they changed wages in unison [Dublin, 1993, pp. 10, 21, McGouldrick, 1968, p. 37]. Moreover, the mills shared a common supply of waterpower, they shared patents and they had interlocking directorates. This gave them the ability to sanction potential defectors. Of course, mills in other towns could attempt to hire away experienced workers, however, relocation costs were significant and temporary workers were usually hired under one-year contracts. The associated costs provided the Lowell mills room to earn limited rents.

\footnotetext{
10 For example in 1834 (Table 2) the rents (“depreciation") were $1.3 \notin$ per hour over wages of $4.3 \notin$ per hour. Note that piece rate wages necessarily imply that the firm shared in human capital costs unless workers made transfer payments to the firm during the initial months. But, in fact, the firms subsidized the workers during the time they were paid day wages.

11 See Acemoglu and Pischke [1999] for a literature review.
} 


\section{Human Capital and the Stretch-Out of 1842}

\section{The Profitability of the Stretch-Out}

The change to three looms per worker was accompanied by an increase in labor productivity after an initial dip in 1842-3 (possibly as workers learned to adapt to the new work intensity). Labor productivity increased from an average of 7.9 yards per weaver-hour during 1839 to 10.1 yards per weaver-hour during 1849 , a $27 \%$ increase.

Some part of this increase can be attributed to technical improvements. However, any such improvements did not generate increases in capital productivity (as Zevin [1975] found during the first decade of power weaving) — output per loom hour for a fully trained worker decreased slightly, from 3.93 yards before 1842 to 3.83 yards after. ${ }^{12}$

This means that the stretch-out necessarily increased labor productivity by nearly $50 \%$ for fully trained workers. However, as Figure 2 implies, after 1842 inexperienced workers had relatively lower levels of utilization for a longer time. Thus the stretch-out decreased productivity for workers who were still inexperienced. The net effect depended on the relative proportion of experienced workers in the labor force.

Furthermore, increases in labor productivity translated into increases in profit margins because average hourly wages did not increase — in fact, they decreased slightly from 1839 to 1849. Thus stretching-out could increase or decrease profit margins depending on worker experience. This suggests an answer to the question of why the firms did not use three looms per worker earlier: the profitability of this allocation depended on the ability of the mill's to maintain a higher proportion of experienced workers.

This intuition can be analyzed formally, using the human capital estimates. I use equation (8) to analyze the profitability of different human capital investments at different times. The profitability of an investment depends on price, $p$, the wage, $w$, and the separation rate, $d$. The first two are market variables, but the separation rate may depend on more complex social conditions. The early textile industry did not have an established industrial labor force, a ready pool of trained workers to hire, or institutions to select, train and maintain a stable experienced workforce. The most profitable use of new technology depended on an experienced labor supply with relatively low turnover. And this developed only slowly and with some substantial social innovation.

\footnotetext{
12 Zevin also notes (p. 56) that the technical improvements largely occurred from 1815-24, but the productivity gains were realized later. In contrast, Lyons [1987] finds an increase in capital productivity associated with technical improvements in Britain during the 1840's. Other evidence suggests that the contribution of technical improvements to productivity was limited during the 1840's in Lowell. Lazonick and Brush [1985] note that the Lawrence Company installed new cotton pickers during this period, but find no associated increase in weaving productivity. Regression analysis below (Table 3) finds that technical improvements, represented by the time trend, contributed no more than $0.50 \%$ to productivity growth annually.
} 
13 - Technology and Learning by Factory Workers - July, 2002

Some thumbnail calculations demonstrate the importance of turnover and an experienced labor pool for the firm's allocation of capital per worker. Table 2 illustrates some simple calculations based on Equation (8) for two and three looms in 1834 and 1842.

This equation uses the rate of permanent separations from the industry, $d$, however, the data only reveal separations from the Upper Weaving Room-workers leaving this room could go to other weaving rooms in this or other mills. On the other hand, this room hired experienced workers. A certain percent of the workers leaving any particular mill were retained in the Lowell labor force and could be hired by other mills, perhaps after a stint of unemployment. To estimate this retention rate, I assume that these flows in and out of the Upper Weaving Room were in equilibrium. That is, for any period, the number of workers who left the Upper Weaving Room and found work in another weaving room equals the number of experienced workers hired into the Upper Weaving Room. The retention rate is, then, the number of experienced workers hired divided by the total number of separations. The rate of permanent separations is the gross rate of separations times one minus the retention rate.

The resulting values of net profit per worker-hour show a sharp difference: two looms were preferable in 1834, but three were preferable in 1842. Although employers in antebellum Lowell would not have performed exactly these calculations, they may have understood the basic intuition behind these equations, and, at the very least, the experiments of 1842 would have demonstrated the advantage of a change.

Two sorts of changes contribute to the profitability of three looms in 1842: first, product price decreased relative to wages from 1834 to 1842. Second, labor supply conditions improved by 1842 indicated by a lower separation rate and a higher retention rate. Each of these sources of change deserves further examination.

First, consider the role of wages relative to price. Equation (8) implies that higher relative wages may induce firms to invest more in human capital and employ fewer, but more skilled, workers per machine. That is, the cost of human capital investment is foregone output, $C$, and this is valued at the product price. But the resulting labor saving is valued at the market wage. When the wage is relatively high, the benefits are large and firms invest more. When the wage is low, the benefit is not worth the cost and so human capital investment is low. In short, skill substitutes for labor when wages are high relative to prices. ${ }^{13}$

\footnotetext{
13 Note that this is definitely not a simple case of capital substituting for labor. In a standard two-factor model, capital productivity should drop substantially with a 33\% drop in labor per capital. But, as noted, capital productivity remained nearly unchanged. This result appears to be more general. In a cross-country comparison of cotton mills circa 1910, Clark [1987] finds that those countries with high relative wages employed more capital per worker, but they did not have lower output per machine. Clark discounts an interpretation involving experience, however, Clark's measure of experience is quite rough and unlikely to capture the effects measured here with richer data.
} 
14 - Technology and Learning by Factory Workers - July, 2002

But the rise in the relative wage does not, by itself, explain the transition to three looms in Lowell. If the calculations for 1842 are repeated, but only price and wage level are allowed to change from 1834, two looms are still much more advantageous. The higher retention rate and the lower separation rate of the labor supply exerted a larger influence.

This suggests that human capital was decisive in the switch to three looms per worker. Firms could not have profitably used three looms in 1834 because high labor turnover inhibited the needed human capital investment. They had to wait for the maturation of the labor force. This appears to have occurred through the selection of a more stable employed workforce and also with the growth of a pool of experienced workers available for rehire. But this was a slow process that delayed the more efficient implementation of power loom technology.

The stretch-out of 1842 can be described as capital deepening. But it clearly was also a deepening of human capital, as it involved larger investments in skills learned on-the-job. Furthermore, as Lazonick and Brush [1985] have argued, it involved an increase in worker effort. Physical capital, factory skills and worker effort were strong complements, and the stretch-out involved deepening intensity in all of these.

\section{Human Capital and Labor Policy}

\section{Selection and Stability}

Thus the mills responded to a more stable labor supply by deepening their investments in human and physical capital. Given that the mills improved their profits with a more stable labor supply, one wonders whether they pursued labor policies to actually foster labor stability. I argue that major changes in labor policy served, in fact, to maximize the returns on human capital of factory workers, initially by emphasizing selectivity and later by providing stability.

Historical accounts of the cotton industry have emphasized the close link between technical changes and changes in the labor supply. Prior to 1816, most cotton manufacturing took place under the so-called "Rhode Island" system first used by Slater [see Ware, 1931, Kulik et al, 1982, Tucker, 1984]. Whole families were recruited to live and work in mill villages often with company housing and a company store. An advantage of this system was that it provided a supply of child labor often with parental supervision.

A switch to the "Waltham system" accompanied the introduction of the power loom in 1816. At Waltham and Lowell, the mills predominately hired young, literate Yankee farm women for weaving positions. These women were largely hired at an age before they would customarily marry with the expectation that they would work only a few years at most. They came to Lowell 
from all over northern New England. Their time in Lowell was structured to be a rewarding cultural and intellectual experience; they lived in morally supervised boardinghouses, they were expected to attend church, they could attend cultural events and lectures and participate in producing a newspaper and other activities [see Dublin, 1993, for a more complete picture]. As seen in Figure 1, about 95\% of new hires were literate, above the average level of literacy for women at that time [Perlman and Shirley, 1991] and few women with Irish surnames were hired.

And another switch followed the transition to three looms per worker in the 1840s: as discussed above, the new labor force included growing numbers of immigrants and illiterate workers. The boardinghouses and cultural institutions gradually lost support, and the labor force increasingly lived in local private housing.

Ware [1931] and Josephson [1949] attributed this change to employers' loss of philanthropic motivation. Worker skills provide another explanation. From the perspective of worker skills, the main advantage of the Waltham system was its selectivity. In the early years, this allowed the mills to hire a select group of workers who could learn new skills quickly and reliably. Later, however, the Waltham system, based on a transient workforce of young women, proved a poor vehicle for building long term employment relationships. A workforce based on local labor, including immigrants and illiterates, was more suitable for the greater human capital investments after 1842 .

The type of workers in the Waltham system demonstrates this selectivity. As noted, few immigrant or illiterate workers were hired and, unlike the Rhode Island system, the workers were young adults. Below I demonstrate that literate adults had a critical productivity advantage.

Also, this system had a strong job matching mechanism to select those individuals who were most productive. About one third of new hires (half of illiterate hires) would leave during the first three months on the job at the Lawrence Co., either because they found the work distasteful or their performance was unsuitable. In addition, discipline in the factory and in the boardinghouses served to select out those of immoral or insufficiently serious character [Gersuny, 1976]. Indeed, in the early days, the transient nature of the Lowell workforce was seen as an advantage because it avoided a permanent caste of "degraded" workers [Ware, 1931, p. 200].

In contrast, under the Rhode Island system, mills had only limited selectivity. Families were recruited as a unit [see Ware, 1931, p. 199-200]. This meant that the recruited families were likely to be poor and perhaps more often illiterate [Tucker, 1984, p. 79-80]. One mill owner described mill families as "often very ignorant, and too often vicious" [Smith Wilkinson cited in Ware, 1931, p. 200]. Although this remark may not be representative, the mills had limited choice of the families they could recruit. They also had limited choice over individual hires. Householders 
determined which family members would work, sometimes recruiting distant kin or outsiders to fill factory positions, and the householders controlled job assignments and supervised the work [Tucker, 1984, p. 148, 217].

But although the Waltham system had advantages for quickly developing skilled workers for a new technology, it failed to foster a stable workforce. First, literate workers were more likely to leave- they had better opportunities in the labor market (e.g., as schoolteachers) and perhaps also in the "marriage market." In a probit analysis of separation probabilities (not shown), after controlling for ethnicity, real earnings and experience, I found that literate workers' monthly separation rate was $4 \%$ higher than for illiterate workers after the initial three months.

Second, once workers left a Waltham-style mill, they were less likely to be available for rehire. Only 9\% of the young women employed at Boott mills in 1841 came from Lowell [Ware, 1931, p. 219]. These workers tended to leave Lowell once they got married [Dublin, 1993, p. 264] and they very likely also left Lowell when they left the mill for other reasons. As a result, literate workers had a lower retention rate. From 1842 to 1855 I found the mean retention rate for literate workers was $51 \%$; for illiterate workers it was $70 \% .{ }^{14}$ Thus the transition that took place after 1842 was also a transition to a local labor force where many experienced workers, having left the mills, were available for rehire. But this pool of local labor included many immigrants and illiterates; of the workers residing in local private housing, only $45 \%$ were native born. ${ }^{15}$

The shifts in labor policy reflected a changing tradeoff between selectivity and stability in the development of worker skills. The advantage of selectivity in the early years and the shift to stability in the 1840 's is illustrated by counterfactual calculations concerning literacy using the human capital model.

\section{Literacy and On-The-Job Learning}

Consider first the positive effect of literacy. The job of tending a power loom did not involve reading or writing. One might assume, therefore, that literacy was of no significance to this job. Certainly many illiterate workers held factory jobs. Indeed, Mitch [1992] has documented the low level of literacy among English factory workers.

\footnotetext{
14 Calculated as the number of experienced workers of the given type hired over the number of workers of that type who separated during the period as discussed in the text. This method very likely understates the retention rate for illiterate workers because very few were in the workforce at the beginning of this period.

15 Dublin [p. 143] finds that in 1850 that $55 \%$ of the native born lived in company housing while $39 \%$ of the total workforce did. Yankees comprised $61.4 \%$ of the workforce. Therefore $61.4 \%$ x $(100 \%-55 \%) /(100 \%-39 \%)=45 \%$ of the workers living in private housing were native born.
} 
17 - Technology and Learning by Factory Workers - July, 2002

But contemporaries in Lowell felt education was important for weavers. Miles argued that Lowell operatives were superior to their English counterparts because of their education [1846, p. 130]. In 1841, Horace Mann, the Secretary of the Massachusetts State Board of Education, obtained evidence from Lowell employers suggesting that literate operatives earned $18 \%$ to $27 \%$ more than illiterate operatives [Dublin, 1993, p. 150]. Dublin disputes this evidence, arguing that mill agents assigned educated Yankee workers to better jobs and these statistics did not adequately control for job placement.

But evidence from the Lawrence Company reveals that literate workers were at least $12 \%$ more productive, all else equal. To estimate the effect of literacy I perform a regression on individual labor productivity. Using a Cobb-Douglas type specification for equation (3), for the $i$ th worker at time $t$

$$
\ln y_{i t}=b_{n} \cdot \ln n_{t}+b_{z} \cdot \ln z_{i t}+b_{t}+b_{c} \cdot C_{i}+\varepsilon_{i t}
$$

where $y$ is output per hour, $n$ is looms per workers, $z$ is the individual's effective experience (specified below), $C$ represents a vector of individual characteristics including literacy, and $\varepsilon$ is a stochastic error. The time dummies, $b_{t}$, capture mill-wide changes in technology, managerial capabilities, etc.

Following the discussion above, the learning period for individuals varies with the number of looms per worker. To capture this, I specify $\bar{x}(n)=b_{k} \cdot n^{\alpha}$, so that effective experience is

$$
z_{i t} \equiv \min \left[x_{i t}, b_{k} \cdot n_{t}^{\alpha}\right]
$$

where $x$ is days worked, and $b_{k}$ and $\alpha$ are to be estimated. This specification is folded back into equation (9) for estimation.

Since this form is nonlinear, I use maximum likelihood estimation. Column 1 of Table 3 shows estimates with individual fixed effects and a time trend. Column 2 replaces the individual fixed effects with individual characteristics and column three uses time dummies.

In all estimates, the coefficients for experience variables are highly significant. The estimates of $b_{k}$ and $\alpha$ generate learning periods of 6 months for two looms per worker and 12 months for three looms per worker, corresponding well with Figure 2. 
Note that $b_{n}$ is negative. ${ }^{16}$ This might seem disturbing, except recall that machinery enters the equation (9) in two different places $-n$ also affects the level of effective experience. This means that the output elasticity of capital depends on the individual worker's experience, as suggested above. For an inexperienced worker $(x<\bar{x})$, the elasticity is just $b_{n}=-.12$, using the values from column 3. In effect, this coefficient simply implies that an inexperienced worker was slightly less productive in the early months tending three looms rather than two. This interpretation is born out by examination of mean productivity levels during the first three months (not shown). But for an experienced worker $(x>\bar{x})$, the output elasticity of capital is $b_{n}+b_{z} \cdot \alpha=+.81$, a more typical value. In other words, the number of looms per worker and the human capital per worker were strong complements. ${ }^{17}$

Columns 2 and 3 show estimates that literate workers were $17-18 \%$ more productive. However, these estimates may be biased upwards because illiterate workers were more likely to quit during the first few months. To correct for this, in column 4, I regress the fixed effects from column 1 on individual characteristics (one observation per individual). ${ }^{18}$ Here literate workers are over $12 \%$ more productive at a high level of significance (other characteristics were at best marginally significant).

Although weaving did not involve reading and writing, literacy signaled higher productivity, apparently either because literate workers could learn better or were more used to performing patient detail work. But, as noted above, literate workers had a higher separation rate and a lower retention rate.

The combined effect of the greater productivity and higher separation rate is illustrated in Table 4. This repeats the simplified pro-forma calculations in Table 2 for the preferred number of looms in 1834,1842 and 1854 . But the calculation is performed separately for literate and illiterate workers in each year. In the columns for literate workers, both productivity and piece rate wages are $12 \%$ higher. Actual separation rates are included. ${ }^{19}$

\footnotetext{
16 The number of looms per worker is correlated with the time variable, raising the possibility of multi-collinearity. To test for this, I calculated the Belsey, Kuh, Welsch [1980] condition number for the linear regressions. These suggest there is sufficient independent variation in $n$ to produce reliable estimates.

17 Applying these output elasticities to 1842, an increase from two looms to three looms per worker would have decreased the labor productivity of an inexperienced worker by $5-10 \%$, but it would have increased the productivity of an experienced worker by $34-9 \%$, across all three specifications.

18 The year dummies now correspond to the individual's starting year.

19 The separation rates are the averages for 1833-36 for the 1834 columns, averages for $1842-50$ for the 1842 columns, and 1852-5 for the 1854 columns. The retention rates are for 1833-36, 1842, and 1852-55 for the three sets of columns. For simplicity, no adjustment was made for different quit rates during training.
} 
19 - Technology and Learning by Factory Workers - July, 2002

These estimates understate the advantage of illiterate workers for two reasons. First, although mainly literate workers resided in subsidized boardinghouses [Dublin, 1993, p. 155], Table 4 ignores the cost of this subsidy. Second, Table 4 uses the same retention rate for both literate and illiterate workers, despite higher retention of illiterate workers (above). To the extent that each firm considered the benefit of the pool of experienced labor in its hiring decisions, illiterate workers would have a greater advantage. ${ }^{20}$

Despite this bias, Table 4 shows a slow, distinct shift of advantage in favor of illiterate workers. In 1834 literate workers were quite profitable, but the Lawrence Company would lose money hiring illiterate workers. By 1842, however, illiterate workers were profitable, though less profitable than literate workers - mills might reasonably hire a few illiterate workers with strong positive unobserved characteristics. By 1854 illiterate workers were significantly more profitable for four looms per worker.

As the economic advantage shifted toward illiterate workers, the mill began hiring a larger share of these workers. This occurred slowly at first after 1842 when still only a small percentage of hires were illiterate. As the mills began hiring more local workers, including immigrants and illiterates, the pool of these workers available for rehire grew. As can be seen in Figure 1, the percentage of new hires with experience grew and after 1845 this growth consisted largely of experienced workers who were Irish and/or illiterate. This, in turn, made illiterate workers more advantageous. Also, their separation rate declined as, perhaps, they found less discrimination. Most significant, the greater human capital investment with four looms per worker shifted the advantage further toward a stable workforce.

Thus employers appear to have changed hiring policy in the 1840's not simply because their philanthropic instinct abated, but because it was profitable to do so. And it was profitable because worker skills, learned through experience, mattered.

\section{Conclusion}

The experience level of ordinary factory workers is a key factor in understanding the changes in technique, labor policy, and social institutions that took place around the stretch-out of 1842. Factory workers learned skills on the job that allowed them to increase their productivity rapidly over several months. This pattern implies a human capital investment and I show that the textile firms paid for most of this investment. Yet in order for this human capital investment to be profitable, the firms needed to find the right match between labor policies and social conditions.

\footnotetext{
${ }^{20}$ Firms would realize a private benefit when workers it had previously trained were rehired at another weaving room in the same firm. Also, firms, given their close cooperation on other issues, may have partially internalized the externality of the pool.
} 
The pace and nature of technology implementation depended on the institutional means used to acquire the necessary skills.

Consider for example, Habakkuk's argument [1962] that higher American wages were responsible for American firms choosing more capital intensive techniques than in Britain. In fact, the stretch-out of 1842 marked the major point of divergence between British and American power weaving techniques. Britain continued to assign two power looms per worker in the 1840s and British power weavers tended fewer looms than their American counterparts for the remainder of the century [Copeland, 1912, p. 90]. The analysis above suggests that wages may have exerted some influence, but that wages and prices were not decisive in inducing this change. Differences in labor skills and in product markets (e.g., greater standardization in America may have reduced the required human capital investment) may prove more significant. ${ }^{21}$

Skill acquisition also affected the pace of technological change at Lowell. The main reason firms took decades to invest in worker skills to the level of the 1850 s was that the profitability of this investment depended on a slowly changing labor supply and supporting institutions. E. P. Thompson [1964] and others have highlighted how the development of a self-disciplined working class paced the adoption of new technology. The socialization of workers very likely played an important background role at Lowell, but this paper reveals important links specifically between the nature of the labor supply, worker skills, and technical implementation. The profitability of human capital investment improved as the workforce became more stable and as a pool of trained workers emerged in Lowell, encouraged by new labor policies. The problem was not simply that individual workers had to acquire experience - that required only a year or less. Rather the problem was to develop social institutions that permitted the maintenance of an experienced workforce, and that took much longer.

In other words, the effective implementation of the power loom was a broad social process, not just an elite process driven by a few inventors, mechanics and entrepreneurs (in this case, Lowell and Moody). The picture of power weaving in ante-bellum Lowell suggests that this development was as much a process of social innovation as of technological innovation. The great inventions and subsequent incremental technical improvements were critically important, but efficient implementation also required worker skills and the associated slowly-developed social innovations.

\footnotetext{
21 Brito and Williamson [1973] argue that a lower skill premium in America permitted higher capital utilization. Harley [1974], on the other hand, argues that a greater supply of skilled labor in Britain allowed firms to substitute skill for capital. In these models, however, the skill premium is exogenous and is measured by occupational differences.
} 
21 - Technology and Learning by Factory Workers - July, 2002

More generally, weaving in the nineteenth century appears as a series of social experiments designed to facilitate the acquisition of worker skills: first, the Waltham system where literate farm girls housed in company boardinghouses tended the first power looms (replacing the earlier model of mill villages, itself a social innovation). Then in the 1840s, this gave way to a labor supply that also included immigrant and illiterate labor, now residing permanently in the factory town. This change permitted greater human capital investment and more productive implementation of the power loom. The end of the nineteenth century saw the adoption of the automatic loom and many more looms per worker. Saxonhouse and Wright argue [1984, Wright, 1986] that this technological innovation, too, was intimately connected to social innovations, particularly in the development of an adult male labor supply in the South.

\section{Appendix}

\section{Description of Lawrence Company Data}

The dataset for the Upper Weave Room of Lawrence Company Mill No. 2 was obtained from payroll records from 1833-1836 and 1838-1855 at the Baker Library Historical Collections at Harvard Business School. Lazonick and Brush [1985] originally collected most of this data and graciously shared it. To their data I added records for 1833 and provided some general cleaning. The resulting data include 15,945 monthly observations on 1,963 individuals. Each record includes name, days worked, earnings, piece rate (if on piece rate), pieces produced, signature (indicating literacy) and supplementary data including hours per day, total pieces produced, and yards per piece. The production of individual dayhands is not recorded, however, total production is recorded allowing the average productivity of dayhands to be calculated. I estimated an average rate for dayhands of 0.66 pieces per day over the entire sample with little evidence of any trend.

Productivity calculations assign dayhands this production rate. Alternate calculations show that the human capital estimates and productivity regressions are not particularly sensitive to this figure.

\section{Calculating Human Capital Investment}

The standard measure of human capital investment is obtained from foregone earnings or foregone output [Becker, 1993], depending on whether the investment is made by employee or employer. Given the high employee separation rate at Lowell, it is helpful to present a simple model of human capital that includes separations.

Index time periods by $t=0,1, \ldots$ The worker receives wages and the firm collects revenues at the end of each period. For simplicity, initially assume that all learning activity takes 
place the first period a worker is hired. During this period, a worker earns wage $w_{0}$ and produces output $y_{0}$. Subsequently, a fully trained worker, if still employed at the firm, earns $w_{T}$ and produces output $y_{T}$.

At the end of each period, there is a hazard $d$ that any worker will be fired or will quit. For simplicity, I initially assume this hazard is constant. Also, I assume that once a worker separates from the firm, she cannot use these learned skills elsewhere and returns to alternative employment at market wage $w .^{22}$

The worker's expected present value can be calculated as follows. At the end of the first period $(t=0)$, the worker's discounted earnings are $\frac{w_{0}}{1+r}$, assuming a constant discount rate of $r$. For subsequent periods $(t>0)$, if the worker is still employed at the firm, with probability $(1-d)^{t}$, the worker's discounted earnings are $\frac{w_{T}}{(1+r)^{t+1}}$. On the other hand, with probability $d \cdot(1-d)^{t-1}$ the worker will separate from the firm beginning in the $t$ th period, earning a termination value in alternative employment of $\frac{w / r}{(1+r)^{t}}$. Putting all of these together, the worker's expected present value at the beginning of employment is

$$
\begin{aligned}
W & =\frac{w_{0}}{1+r}+\sum_{t=1}^{\infty} \frac{(1-d)^{t} w_{T}}{(1+r)^{t+1}}+\sum_{t=1}^{\infty} \frac{d \cdot(1-d)^{t-1} w / r}{(1+r)^{t}} \\
& =\frac{w_{T}+d \cdot w / r-(d+r) \cdot I_{w}}{d+r}, I_{w} \equiv \frac{w_{T}-w_{0}}{1+r}
\end{aligned}
$$

where $I_{w}$ is the value of discounted foregone earnings relative to the wage of a fully trained worker, $w_{T}$; as above, this equals the worker's human capital investment.

Now if labor markets are competitive, $W$ should equal the value of alternative work at the market wage. That is,

$$
W=\frac{w}{r}
$$

Solving this for $w_{T}$ yields

\footnotetext{
22 In practice, the separation rate is adjusted to allow employees to work at other firms and to allow firms to hire previously trained workers. In effect, $d$ is the rate of employee separations from the local industry. It also may vary from month to month. The exposition is made simpler without these considerations.
} 


$$
w_{T}=w+(d+r) \cdot I_{w} .
$$

Following standard human capital analysis, the second term on the right is the return on human capital investment, and the worker's human capital investment is $I_{w}$. The separation rate, $d$, acts like the "depreciation" on human capital. Note also that a little algebra shows that

$$
I_{w}=\frac{w-w_{0}}{1-d}
$$

When $d=0$, the human capital investment takes the more familiar form of $w-w_{0}$, earnings foregone relative to alternative employment.

A similar process generates an expression for the firm's human capital investment.

Designate the output price as $p$ and the rental cost of capital per machine as $c$. During periods with new hires, the firm will earn profits per worker (before discounting) of $\pi_{0} \equiv p \cdot y_{0}-w_{0}-n \cdot c$. During periods with fully trained workers, profits will be $\pi_{T} \equiv p \cdot y_{T}-w_{T}-n \cdot c$. Since the firm replaces every worker who separates from the firm, the probability that a worker will be a new hire during any period after the first period is $d$ and the probability that the worker will be fully trained is $1-d$. The expected present value of a worker to the firm is then

$$
\begin{aligned}
F & =\frac{\pi_{0}}{1+r}+\sum_{t=1}^{\infty} \frac{d \cdot \pi_{0}+(1-d) \cdot \pi_{T}}{(1+r)^{t+1}} \\
& =\frac{\pi_{T}-(d+r) \cdot I_{f}}{r}, \quad I_{f} \equiv \frac{\pi_{T}-\pi_{0}}{1+r}
\end{aligned}
$$

where, as above, $I_{f}$ is the firm's discounted foregone profit. Assuming that the firm is in equilibrium regarding its investment activities, $F$ will equal the present value of profits the firm could earn in other activities, $F=\pi / r$. So, considering (A5),

$$
\pi_{T}=\pi+(d+r) \cdot I_{f} .
$$

The term $(d+r) \cdot I_{f}$ represents the rent on the firm's human capital investment including "depreciation". $\pi$ is the alternative profit stream, but in a steady state equilibrium, where the firm replaces all workers who leave, steady state profits, $\bar{\pi}$, must equal $\pi$ :

$$
\bar{\pi}=\pi_{T}-(d+r) \cdot I_{f}=p \cdot y_{T}-w_{T}-n \cdot c-(d+r) \cdot I_{f} .
$$

The total human capital investment can be calculated 


$$
I \equiv I_{w}+I_{f}=\frac{p \cdot\left(y_{T}-y_{0}\right)}{1+r}
$$

just the discounted value of foregone output. Note that inserting (A3) and (A7) into (A6) yields a useful alternative expression

$$
\bar{\pi}=p \cdot y_{T}-w-n \cdot c-(d+r) \cdot I .
$$

This simple model of one period learning can be extended to learning over multiple periods. I calculated two different versions of human capital investment over multiple periods. First, suppose a worker takes $T$ periods to complete training and the worker produces $y_{t}$ and earns $w_{t}$ in each period prior to $T, t=0,1, \ldots T-1$. Then the investments in a worker who completes training are (by similar process)

$$
I^{*}=\sum_{i=0}^{T-1} \frac{p \cdot\left(y_{T}-y_{i}\right)}{(1+r)^{i+1}} \text {, and } I_{w}^{*}=\sum_{i=0}^{T-1} \frac{\left(w_{T}-w_{i}\right)}{(1+r)^{i+1}} .
$$

Note that this is the investment in a worker, conditional on that worker completing training.

With multi-period learning, however, workers may quit or be fired before completing training. In fact, separation rates were greatest during the first three months at Lowell. To obtain one fully trained worker, the firm had to hire more than one worker on average. Also, workers will take into account the possibility that they may not complete training. Suppose that separation rates vary for each period during training, the set of rates being $\left\{d_{0}, d_{1}, \ldots, d_{T}\right\}$, designating the separation rate after training as $d_{T}$. Then this situation may be modeled as a discrete Markov chain. Workers with different amounts of training are in different "states," indexed by the number of months of training, $s, 0 \leq s \leq T$. The probability that a worker has had $s$ months of training is the state variable and a transition matrix can be constructed from the $d_{i}$. By repeatedly applying the transition matrix to an initial state vector $\{1,0,0 \ldots\}$, I calculated the present value of the profit stream of a worker, $\hat{F}$. Then, assuming $\hat{F}=\pi / r$, and using (A8),

$$
\hat{I}=\frac{p \cdot y_{T}-w-n \cdot c-r \cdot \hat{F}}{d_{T}+r} .
$$

A similar procedure yields numeric estimates for the worker's investment, $\hat{I}_{w}$.

This second measure of human capital investment requires more information and is more complex to calculate than the first measure. It may be larger or smaller than the first measure, however, for the separation patterns at the Lawrence Company (with a declining proportional hazard), the second measure turns out to be substantially larger. In general, if one assumes a 
significantly declining hazard, then the first measure can be considered a lower bound estimate of total human capital investment.

\section{References}

Acemoglu, Daron and Jörn-Steffen Pischke (1999), "Beyond Becker: Training in Imperfect Labor Markets," The Economic Journal. v. 109, p. F112-F142.

Allen, Z. (1832), The Practical Tourist. in G. Kulik, R. Parks, and T. Penn (eds, 1982), The New England Mill Village 1790-1860, Cambridge, MA: MIT Press.

Allen, Z. (1861), Historical, Theoretical, and Practical Account of Cotton Manufacture. in G. Kulik, R. Parks, and T. Penn (eds, 1982), The New England Mill Village 1790-1860, Cambridge, MA: MIT Press.

Appleton, N. (1858), Introduction of the Power Loom and Origin of Lowell. Lowell, MA: Penhallow.

Argote, L. and Epple, D. (1990), 'Learning Curves in Manufacturing.' Science. 920.

Auerswald, P., Kauffman, S., Lobo, J. and Shell, K (2000), 'The Production Recipes Approach to Modeling Technological Innovation: An Application to Learning by Doing.' Journal of Economic Dynamics and Control 24, 389-450.

Batchelder, S. (1863), Introduction and Early Progress of the Cotton Manufacture in the United States. (reprinted 1972), Clifton, NJ: Kelley.

Becker, G. (1993), Human capital; a theoretical and empirical analysis, with special reference to education. Third Edition, Chicago: University of Chicago Press.

Belsey, D., E. Kuh and R. Welsch (1980), Regression Diagnostics: Identifying Influential Data and Sources of Collinearity, New York: John Wiley and Sons.

Bernard, Richard M. and Maris A. Vinovskis, (1977), "The Female School Teacher in AnteBellum Massachusetts," Journal of Social History, v. 10, p. 332-345.

Boot, H. M. (1995), 'How Skilled were Lancashire Cotton Factory Workers in 1833?.' Economic History Review 48, 283-303.

British Parliamentary Papers.

Brito, D. and Williamson, J. (1973), 'Skilled Labor and Nineteenth Century Anglo-American Managerial Behavior.' Explorations in Economic History 10, 235-51.

Catling, H. (1970), The Spinning Mule. London: Newton, Abbot, David and Charles.

Clark, G. (1987), 'Why Isn't the Whole World Developed? Lessons from the Cotton Mills.' Journal of Economic History 47, 141-173.

Copeland, M. (1912), The Cotton Manufacturing Industry of the United States. Cambridge, Mass.: Harvard University.

Crafts, N. F. R. (1995), "Exogenous of Endogenous Growth? The Industrial Revolution Reconsidered," Journal of Economic History 55, 745-772.

David, P. (1975), Technical Choice, Innovation and Economic Growth. Cambridge University Press, Chaps. 2 and 3. 
Davis, L. and Stettler, L. (1966), 'The New England Textile Industry 1825-1860.' in NBER, Output, Employment, and Productivity in the United States after 1800, New York: Columbia University Press.

Dublin, T. (1993), Women at Work: The Transformation of Work and Community in Lowell, Massachusetts, 1826-1860, $2^{\text {nd }}$ edition. New York: Columbia University Press.

Elbaum, B. (1989), 'Why Apprenticeship Persisted in Britain But Not in the United States.' Journal of Economic History 49, 337-349.

Elbaum, B. and Singh, N. (1995), 'The Economic Rationale of Apprenticeship Training: Some Lessons from British and U.S. Experience.' Industrial Relations 34, 593-622.

Gersuny, Carl. (1976) “ 'A Devil in Petticoats' and Just Cause: Patterns of Punishment in Two New England Textile Factories," Business History Review, L, p. 131-152.

Gibb, G. (1950), The Saco-Lowell Shops: Textile machinery building in New England 18131949. New York: Russell \& Russell.

Goldin, Claudia and Kenneth Sokoloff (1984), "The Relative Productivity Hypothesis of Industrialization: the American case," Quarterly Journal of Economics, v. 99, p. 461-88.

Habakkuk, H. (1962), American and British Technology in the Nineteenth Century. Cambridge, UK: Cambridge University Press.

Harley, C. K. (1974), 'Skilled Labor and the Choice of Technique in Edwardian Industry.' Explorations in Economic History 11, 391-414.

Harvard Business School, Baker Library Historical Collections, Records of the Lawrence Company.

Hashimoto, M. (1981), 'Firm-Specific Human Capital as a Shared Investment.' American Economic Review 71, 475-482.

Josephson, H. (1949), Golden Threads; New England Mill Girls and Magnates. New York: Russell \& Russell.

Jovanovic, B. and Nyarko, Y. (1995), 'A Bayesian learning model fitted to a variety of empirical learning curves.' Brookings Papers: Microeconomics. 247.

Kulik, G., Parks, R. and Penn, T. (eds) (1982), The New England Mill Village 1790-1860. Cambridge, MA: MIT Press.

Landes, D. (1969), The Unbound Prometheus. Cambridge University Press.

Lazonick, W. and Brush, T. (1985), 'The 'Horndal Effect' in Early U. S. Manufacturing.' Explorations in Economic History 22, 53-96.

Lyons, J. (1987), 'Powerloom Profitability and Steam Power Costs: Britain in the 1830s.' Explorations in Economic History 34, 392-408.

Margo, Robert A. (2000), Wages \& Labor Markets in the United States, 1820-1860. Chicago: University of Chicago Press.

McGouldrick, P. (1968), New England Textiles in the Nineteenth Century. Cambridge, Mass.: Harvard University Press.

Miles, H. A. (1845), Lowell as it Was, and as it Is. (reprinted 1972) New York: Arno Press.

Mitch, D. (1992), The Rise of Popular Literacy in Victorian England. Philadelphia: University of Pennsylvania Press. 
Mitch, D. (1999), 'The Role of Education and Skill in the British Industrial Revolution.' in J. Mokyr, The British Industrial Revolution: An Economic Perspective. Boulder, CO: Westview Press.

Montgomery, J. (1840), Cotton Manufacture. in D. Jeremy, Technology and Power in the Early American Cotton Industry, (1990), Philadelphia: American Philosophical Society.

More, C. (1980), Skill and the English Working Class, 1870-1914. New York: St. Martins Press.

Muth, J. (1986), 'Search Theory and the Manufacturing Progress Function.' Management Science. 948.

Nickless, P. (1979), 'A New Look at Productivity in the New England Cotton Textile Industry, 1830-1860.' Journal of Economic History 39, 889-907.

Perlman, J. and Shirley, D. (1991), 'When Did New England Women Acquire Literacy?.' William and Mary Quarterly 46, 50-67.

Rosenberg, N. (1967), 'Anglo-American Wage Differences in the 1820's.' Journal of Economic History 27, 221-29.

Saxonhouse, G. (1977), 'Productivity Change and Labor Absorption in Japanese Cotton Spinning, 1891-1935.' Quarterly Journal of Economics 91, 195-219.

Saxonhouse, G. and Wright, G. (1984), 'Two forms of Cheap Labor in Textile History.' In Saxonhouse and Wright (eds.), Technique, Spirit and Form in the Making of the Modern Economies: Essays in Honor of William N. Parker. Research in Economic History Supp. 3, 3-31.

Shlakman, V. (1935), Economic history of a factory town; a study of Chicopee, Massachusetts. (reprinted 1969) New York: Octagon Books.

Sokoloff, Kenneth (1984), "Was the Transition from the Artisanal Shop to the Nonmechanized Factory Associated with Gains in Efficiency? Evidence from the U.S. Manufacturing Censuses of 1820 and 1850," Explorations in Economic History, v. 21, p. 351-382.

Thompson, E. P. (1964), The Making of the English Working Class. London.

Tucker, Barbara M. (1984), Samuel Slater and the Origins of the American Textile Industry, 1790-1860. Ithaca and London: Cornell University Press.

Ure, A. (1836), The Cotton Manufacture of Great Britain. London: Knight.

U. S. Bureau of the Census (1975), Historical Statistics of the United States from Colonial Times to 1970. Washington, DC: Government Printing Office.

von Tunzelman, G. N. (1978), Steam Power and British Industrialization to 1860. Oxford: Clarendon Press.

Ware, C. (1931), The Early New England Cotton Manufacture. Boston and New York: Houghton Mifflin.

Williamson, J. (1972), 'Embodiment, Disembodiment, Learning by Doing and Constant Returns to Scale in the Nineteenth Century Cotton Textiles.' Journal of Economic History 32, 699-705.

Williamson, J. and Lindert, P. (1980), American Inequality: a Macroeconomic History. New York: Academic Press.

Wright, G. (1986), Old South, New South. New York: Basic Books, Chap. 5. 
28 - Technology and Learning by Factory Workers - July, 2002

Zevin, R. (1971), 'The Growth of Cotton Textile Production After 1815.' in R. Fogel and S. Engerman, The Reinterpretation of American Economic History, New York: Harper \& Row, 122-147.

Zevin, R. (1975), The Growth of Manufacturing in Early Nineteenth Century New England. New York: Arno. 


\section{Characteristics of New Hires}

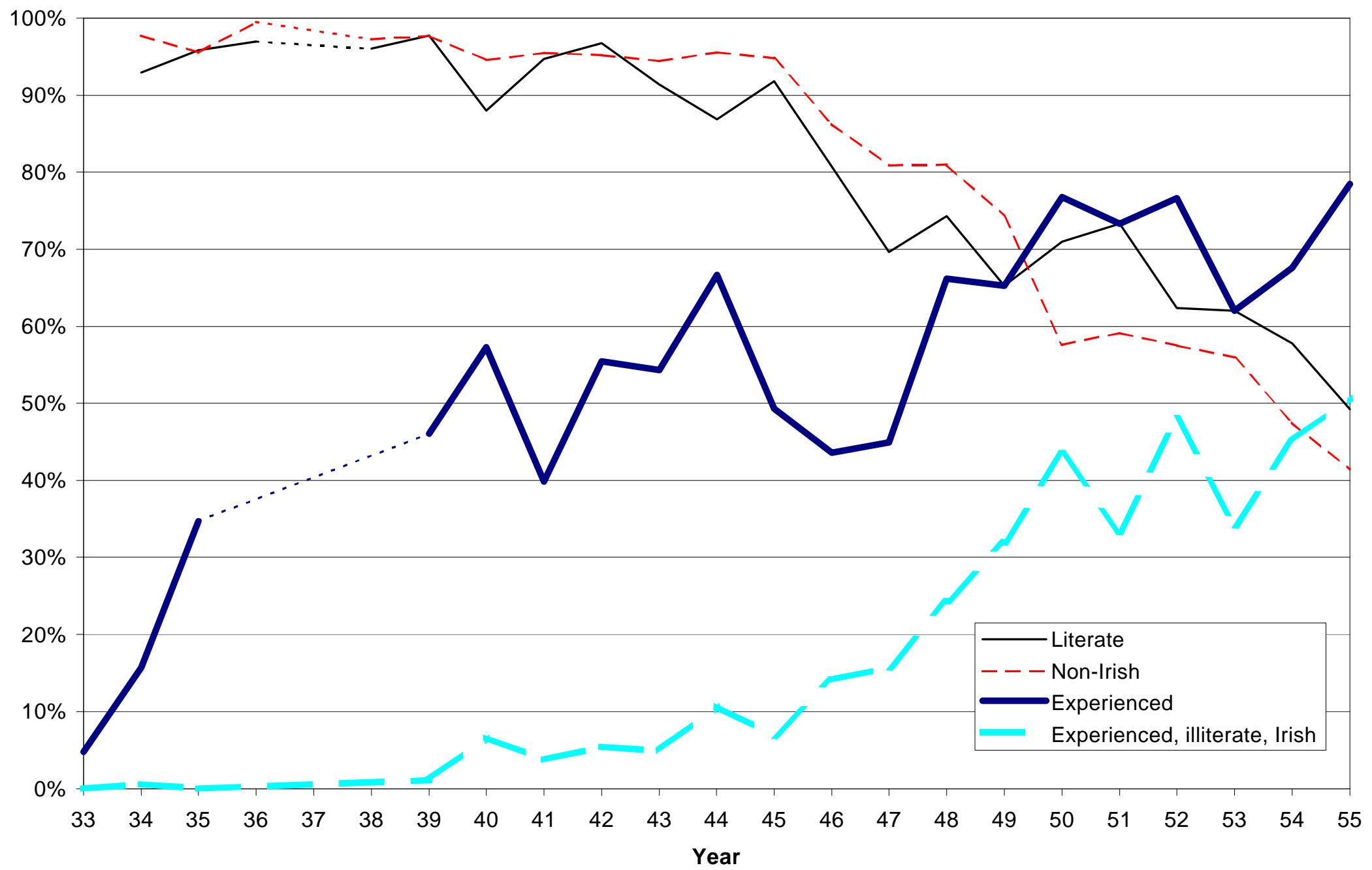

Figure 1. Characteristics of New Hires: Previous Experience, Literacy and Ethnicity, Lawrence Company, Mill No. 2 Upper Weave Room, 1834-55

New hires who did not work dayrate their first month are assumed to have previous experience. Literacy is determined by ability to sign payroll register. Ethnicity is determined by surname. See Lazonick and Brush [1985] for details. Excludes overseers and overseer's assistants. 
Yard per Hour for Weavers, Lawrence Co.

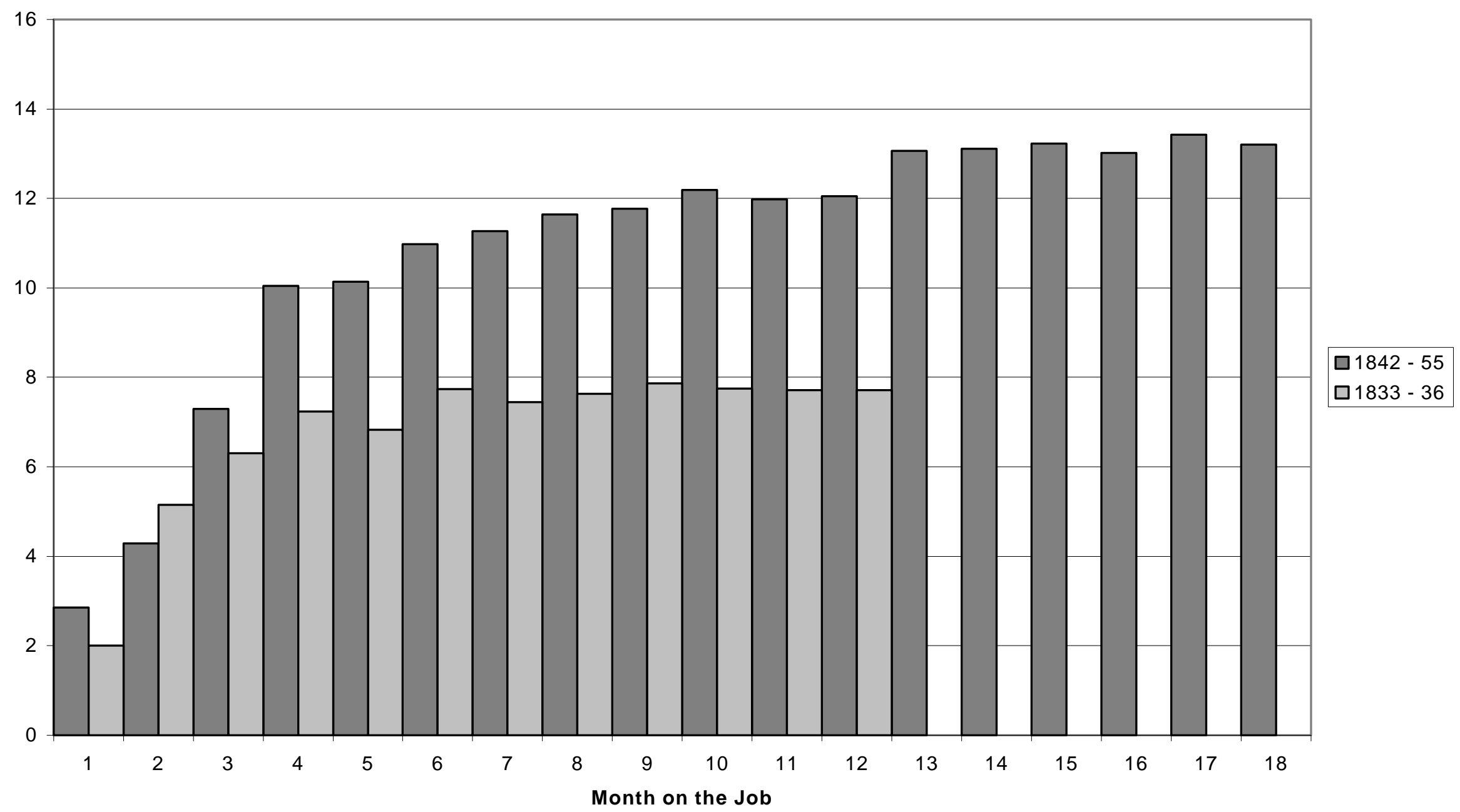

Figure 2. Learning Curve for Loom Tenders in Lawrence Company, Mill No. 2, Upper Weave Room, 1833-36 and 1842-55

Note: Means for balanced panel of 50 (1833-36) and 30 (1842-55) workers who entered the Upper Weaving Room, who worked for at least 12 (or 18) months in this Room. This sample excludes workers who spent no time on day rate (previously experienced) and workers who spend 72 days or more on day rate (permanent dayhands). In calculating yards per hour, workers on day rate were allocated the average productivity of all workers on day rate. 
Figure 3. Worker Human Capital Calculation

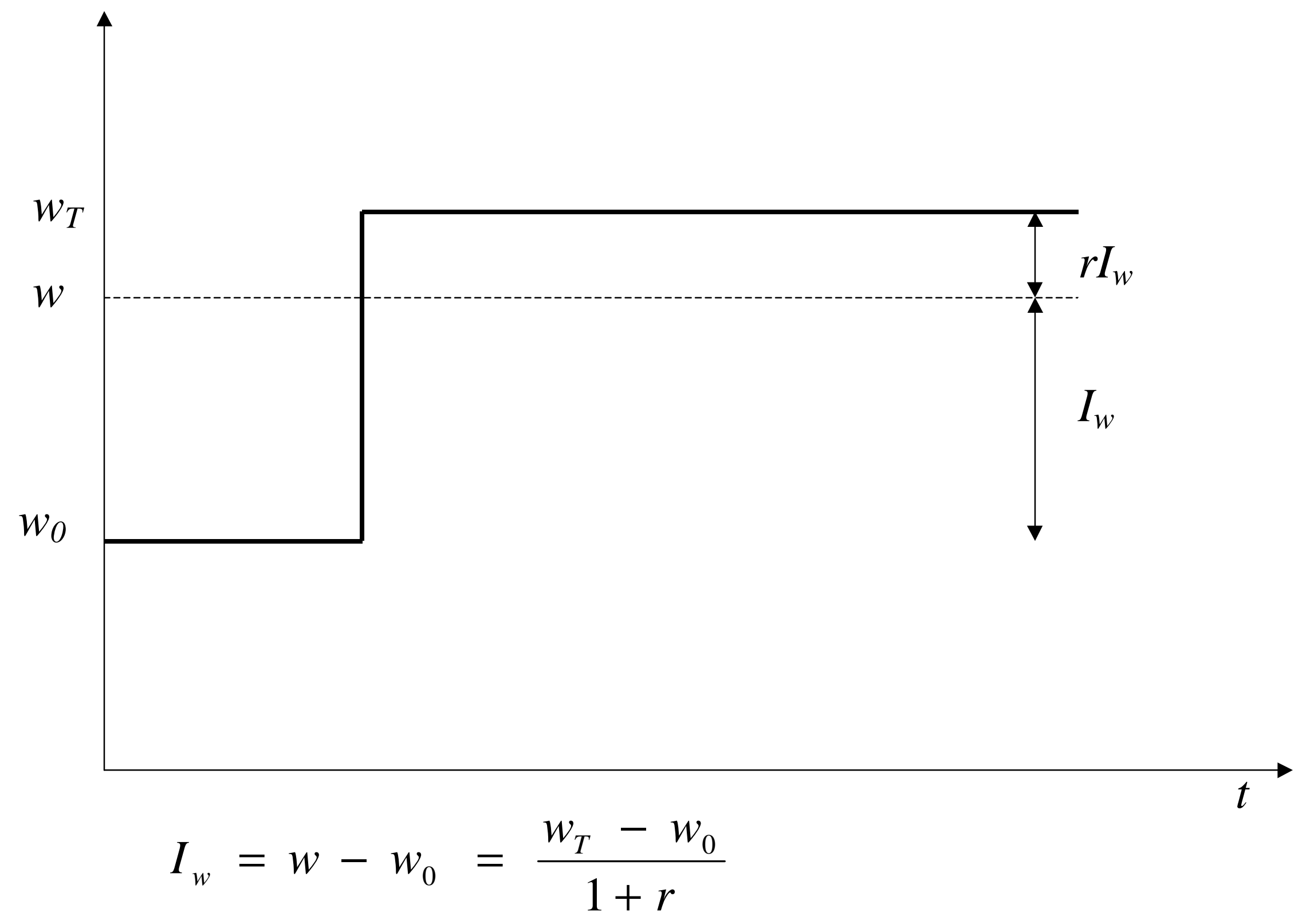

30 - Technology and Learning by Factory Workers 


\section{Table 1. Human Capital Investment Calculations}

\begin{tabular}{|c|c|c|c|}
\hline & & Lawrence & Weavers \\
\hline & & $1833-36$ & $1842-55$ \\
\hline Mean number of days on day rate & & 24.7 & 32.6 \\
\hline Total learning period (months) & $\bar{x}$ & 6 & 11 \\
\hline Estimated physical capital / piecehand & & $\$ 358$ & $\$ 497$ \\
\hline Calculations assuming no separations $d$ & trai & & \\
\hline Foregone output (yards) & $C$ & 2,783 & 10,502 \\
\hline Total human capital investment per worker & $I$ & $\$ 32.56$ & $\$ 94.54$ \\
\hline Worker's human capital investment & $I_{w}$ & $\$ 6.42$ & $\$ 23.31$ \\
\hline Total human capital / annual earnings & & $22 \%$ & $61 \%$ \\
\hline Workers' share of investment & & $20 \%$ & $25 \%$ \\
\hline Calculations allowing separations during & ing & & \\
\hline Total human capital investment per worker & $\hat{I}$ & $\$ 47.39$ & $\$ 161.62$ \\
\hline Worker's human capital investment & $\hat{I}_{w}$ & $\$ 9.03$ & $\$ 32.39$ \\
\hline Total human capital / annual earnings & & $32 \%$ & $104 \%$ \\
\hline Workers' share of investment & & $19 \%$ & $20 \%$ \\
\hline
\end{tabular}

Note: Physical capital estimates based on data from Montgomery [1840]. I assume an annual discount rate of 5\%. I calculated the value of output by compiling average cost (including wages and salaries, general and administrative costs, and capital depreciation, but excluding cotton costs and interest on capital) and applying a markup of $16.5 \%$ (the mean for 6 Lowell companies for the years 1836-55 calculated by McGouldrick [1968, Table 47]). Overhead costs were derived from Montgomery [1840]. Estimates are based on a sample of workers who worked at least 7 months (1833-36) or 11 months (1842-55) without interruption, and who spent some days on dayrate but fewer than 72 days on dayrate. The sample sizes were 111 (1833-36) and 72 (1842-55). Since the length of each month varied, monthly observations of output and wages are calculated by multiplying hourly output and wage rates by average hours per month for the sample. Total human capital / annual earnings is the ratio of total human capital investment to annual earning of a fully trained worker. Workers' share of investment is the ratio of worker's human capital investment to total human capital investment. 


\section{Table 2. Pro-Forma Calculations of Hourly Profit}

\section{Number of looms / worker}

Price / yard for weaving (cents)

Output rate (yards / loom-hour)

Revenue / worker-hour (cents)

Rental cost per loom (cents / hour)

Capital hourly rental cost (cents)

Adjusted hourly wage (cents)

Local monthly separation rate

Retention rate

Permanent separation rate

Foregone output (yards)

Human capital / fully-trained worker

Hourly depreciation / worker (cents)

Net profit / worker (cents / hour)

Net profit / loom (cents / hour)

\begin{tabular}{|c|c|c|c|c|}
\hline \multirow[b]{2}{*}{$n$} & \multicolumn{2}{|c|}{1834} & \multicolumn{2}{|c|}{1842} \\
\hline & 2 & 3 & 2 & 3 \\
\hline \multirow[t]{2}{*}{$p$} & 1.21 & 1.21 & 1.02 & 1.02 \\
\hline & 3.93 & 3.83 & 3.93 & 3.83 \\
\hline \multirow{3}{*}{$c$} & 9.5 & 13.9 & 8.0 & 11.7 \\
\hline & 1.5 & 1.5 & 1.5 & 1.5 \\
\hline & 3.0 & 4.5 & 3.0 & 4.5 \\
\hline \multirow[t]{2}{*}{$w$} & 4.3 & 4.3 & 4.5 & 4.5 \\
\hline & $14.6 \%$ & $14.6 \%$ & $\begin{array}{c}11.6 \% \\
48 \%\end{array}$ & $11.6 \%$ \\
\hline$d$ & $12 \%$ & $12 \%$ & $6 \%$ & $6 \%$ \\
\hline$C$ & 2,783 & 10,502 & 2,783 & 10,502 \\
\hline$p C$ & $\$ 33.67$ & $\$ 127.07$ & $\$ 28.39$ & $\$ 107.12$ \\
\hline$d p C$ & 1.3 & 5.1 & 0.6 & 2.1 \\
\hline \multirow[t]{2}{*}{$\pi$} & 0.8 & 0.0 & -0.1 & 0.6 \\
\hline & 0.4 & 0.0 & 0.0 & 0.2 \\
\hline
\end{tabular}

Note: Values in cents per hour. The price per yard for weaving is based on realized cost per yard marked up 16.5\% (from McGouldrick, 1968). The outputs per loom hour are the values for the fully trained workers in the samples used to calculate human capital investments. Capital rental costs are derived from

Montgomery's data and include depreciation, insurance, interest at 5\% and overhead costs. Although workers were paid by the piece, I use hourly earnings for fully trained workers, adjusted (see Appendix) by subtracting the worker's share of human capital rent $(20 \%)$. Retention rates are determined as the ratio of new hires with experience to separations. Permanent separation rate is local separation rate time one minus the retention rate. 
Table 3. Individual Production Functions

Dependent variable: Log yards per hour for each worker each month (Column 4: Fixed Effects from Column 1)

\begin{tabular}{|c|c|c|c|c|}
\hline & 1 & 2 & 3 & 4 \\
\hline & $M L$ & $M L$ & $M L$ & OLS \\
\hline $\begin{array}{l}\text { Log looms per worker } \\
(\ln n)\end{array}$ & $\begin{array}{l}-.258 \\
(.046)\end{array}$ & $\begin{array}{l}-.269 \\
(.049)\end{array}$ & $\begin{array}{l}-.117 \\
(.055)\end{array}$ & -- \\
\hline $\begin{array}{l}\text { Log effective experience } \\
(\ln z)\end{array}$ & $\begin{array}{l}.611 \\
(.006)\end{array}$ & $\begin{array}{l}.589 \\
(.006)\end{array}$ & $\begin{array}{l}.584 \\
(.006)\end{array}$ & -- \\
\hline Year (trend) & $\begin{array}{l}-.008 \\
(.003)\end{array}$ & $\begin{array}{l}.005 \\
(.001)\end{array}$ & & -- \\
\hline Year dummy variables & & & $\checkmark$ & $\checkmark$ \\
\hline$b_{k}$ & $\begin{array}{l}47.76 \\
(2.63)\end{array}$ & $\begin{array}{l}44.11 \\
(2.70)\end{array}$ & $\begin{array}{l}49.89 \\
(3.19)\end{array}$ & -- \\
\hline$\alpha$ & $\begin{array}{l}1.71 \\
(.07)\end{array}$ & $\begin{array}{l}1.69 \\
(.06)\end{array}$ & $\begin{array}{l}1.58 \\
(.06)\end{array}$ & -- \\
\hline$\frac{\text { Individual Characteristics }}{\text { Literate }}$ & & $\begin{array}{l}.170 \\
(.011)\end{array}$ & $\begin{array}{l}.182 \\
(.011)\end{array}$ & $\begin{array}{l}.127 \\
(.031)\end{array}$ \\
\hline Non-Irish & & $\begin{array}{l}.079 \\
(.013)\end{array}$ & $\begin{array}{l}.109 \\
(.013)\end{array}$ & $\begin{array}{l}.089 \\
(.040)\end{array}$ \\
\hline Previously Experienced & & $\begin{array}{l}.114 \\
(.016)\end{array}$ & $\begin{array}{l}.128 \\
(.016)\end{array}$ & $\begin{array}{l}.008 \\
(.015)\end{array}$ \\
\hline Employment gaps & & $\begin{array}{l}.033 \\
(.008)\end{array}$ & $\begin{array}{l}.039 \\
(.008)\end{array}$ & $\begin{array}{l}.017 \\
(.021)\end{array}$ \\
\hline Individual Fixed Effects & $\checkmark$ & & & \\
\hline$R^{2}$ & .80 & .59 & .60 & .12 \\
\hline
\end{tabular}

Note: Number of observations is 14,306 (1,386 for col. 4). This excludes workers who appear in the payroll records for only one month, months of known water power shortages and observations of experienced workers on dayrate. Constant term not shown. Asymptotic standard errors in parentheses. For OLS estimation, standard errors are heteroscedastic-consistent. The number of looms per worker is the average for the Upper Weaving Room. Effective experience is $\min (x, \bar{x})$ where $x$ is the number of days worked. $\bar{x}=b_{k} \cdot n^{\alpha}$. The OLS estimation uses fixed effects from Column 1 as dependent variable. Literacy was judged by ability to sign name in payroll register. Probability of Irish background was assigned based on surname [see Lazonick and Brush, 1985]. Workers who did not work on day rate their first month were assumed to have previous experience. The employment gap dummy is 1 if the worker's name was missing from the payroll register for the Upper Weaving Room for one or more months, but reappeared subsequently. 
Table 4. Pro-Forma Calculations of Hourly Profit with Literacy

\section{Number of looms / worker}

Price / yard for weaving (cents)

Output rate (yards / loom-hour)

Revenue / worker-hour (cents)

Rental cost per loom (cents / hour)

Capital hourly rental cost (cents)

Adjusted hourly wage (cents)

\begin{tabular}{|c|c|c|c|c|c|c|c|c|}
\hline \multirow[b]{2}{*}{$n$} & \multicolumn{2}{|c|}{1834} & \multicolumn{2}{|c|}{1842} & \multicolumn{4}{|c|}{1854} \\
\hline & $\begin{array}{l}\text { Literate } \\
\quad 2\end{array}$ & $\begin{array}{c}\text { Illiterate } \\
\mathbf{2}\end{array}$ & $\begin{array}{l}\text { Literate } \\
\mathbf{3}\end{array}$ & $\begin{array}{c}\text { Illiterate } \\
\mathbf{3}\end{array}$ & $\begin{array}{c}\text { Literate } \\
\quad \mathbf{3}\end{array}$ & $\begin{array}{c}\text { Illiterate } \\
\mathbf{3}\end{array}$ & $\begin{array}{c}\text { Literate } \\
\mathbf{4}\end{array}$ & $\begin{array}{c}\text { Illiterate } \\
\quad 4\end{array}$ \\
\hline \multirow[t]{2}{*}{$p$} & 1.21 & 1.21 & 1.02 & 1.02 & 0.90 & 0.90 & 0.90 & 0.90 \\
\hline & 3.93 & 3.51 & 3.83 & 3.42 & 3.83 & 3.42 & 3.83 & 3.42 \\
\hline \multirow{3}{*}{$c$} & 9.5 & 8.5 & 11.7 & 10.5 & 10.3 & 9.2 & 13.7 & 12.3 \\
\hline & 1.5 & 1.5 & 1.5 & 1.5 & 1.5 & 1.5 & 1.5 & 1.5 \\
\hline & 3.0 & 3.0 & 4.5 & 4.5 & 4.5 & 4.5 & 6.0 & 6.0 \\
\hline$w$ & 4.4 & 3.9 & 4.5 & 4.0 & 4.5 & 4.0 & 4.5 & 4.0 \\
\hline
\end{tabular}

Monthly local separation rate

Retention rate

Permanent separation rate

Foregone output (yards)

Human capital / fully-trained worker

Hourly depreciation / worker (cents)

\section{Net profit / worker-hour (cents)}

Net profit / loom-hour (cents)

\begin{tabular}{|c|c|c|c|c|c|c|c|c|}
\hline \multirow[t]{3}{*}{$w$} & 4.4 & 3.9 & 4.5 & 4.0 & 4.5 & 4.0 & 4.5 & 4.0 \\
\hline & $12.4 \%$ & $19.1 \%$ & $11.8 \%$ & $10.1 \%$ & $14.0 \%$ & $8.6 \%$ & $14.0 \%$ & $8.6 \%$ \\
\hline & $16 \%$ & $16 \%$ & $48 \%$ & $48 \%$ & $68 \%$ & $68 \%$ & $68 \%$ & $68 \%$ \\
\hline$d$ & $10 \%$ & $16 \%$ & $6 \%$ & $5 \%$ & $4 \%$ & $3 \%$ & $4 \%$ & $3 \%$ \\
\hline$C$ & 2,783 & 2,783 & 10,502 & 10,502 & 10,502 & 10,502 & 24,483 & 24,483 \\
\hline$p C$ & $\$ 33.67$ & $\$ 33.67$ & $\$ 107.12$ & $\$ 107.12$ & $\$ 94.20$ & $\$ 94.20$ & $\$ 219.61$ & $\$ 219.61$ \\
\hline$d p C$ & 1.1 & 1.8 & 2.1 & 1.8 & 1.4 & 0.8 & 3.2 & 2.0 \\
\hline \multirow[t]{2}{*}{$\pi$} & 1.0 & -0.2 & 0.5 & 0.1 & -0.1 & -0.2 & 0.0 & 0.3 \\
\hline & 0.5 & -0.1 & 0.2 & 0.0 & 0.0 & -0.1 & 0.0 & 0.1 \\
\hline
\end{tabular}

Note: Values in cents per hour. The price per yard for weaving is based on realized cost per yard marked up 16.5\% (from McGouldrick, 1968). The outputs per loom hour are the values for the fully trained workers in the samples used to calculate human capital investments. Capital rental costs are derived from Montgomery's data and include depreciation, insurance, interest at 5\% and overhead costs. Although workers were paid by the piece, I use hourly earnings for fully trained workers, adjusted (see Appendix) by subtracting the worker's share of human capital rent (20\%). Literate workers are assumed to be $12 \%$ more productive and to earn $12 \%$ more than illiterate workers. Mill separation rates are means for each period for each type of worker. Retention rates are determined as the ratio of new hires with experience to separations. Permanent separation rate is local separation rate time one minus the retention rate. 